\title{
IDEOLOGY AND THE NARRATIVE OF CLIMATE SKEPTICISM
}

\author{
Raul P. Lejano
}

\section{Improved climate science communication may yield limited success because \\ at least some climate skepticism is based on a narrative that is not even \\ fundamentally about climate to begin with.}

S cientific evidence of human-induced climate change continues to build, and at the same time there have been real improvements in communicating that evidence (Leiserowitz et al. 2017). Yet, opposition to the science seems ever deeper and louder. This is especially true in the United States, where a backlash against climate science has reached a fever pitch over the last decade.

This may seem like an age when every source of knowledge is questioned, but surveys suggest that there is no widespread questioning of science; in fact, public trust and support for the scientific industry persists (National Science Board 2018; Pew Research

AFFILIATION: LejANO-Steinhardt School of Culture, Education, and Human Development, New York University, New York, New York

CORRESPONDING AUTHOR: Raul P. Lejano, lejano@nyu.edu

The abstract for this article can be found in this issue, following the table of contents.

DOI:10.1175/BAMS-D-16-0327.I

In final form 4 May 2019

(C)2019 American Meteorological Society

For information regarding reuse of this content and general copyright information, consult the AMS Copyright Policy.
Center 2009). Something about climate denial, however, continues to resonate with many people.

Scholars such as Oreskes and Conway (2010) have recounted how the challenge to climate science stemmed from efforts of political operatives (including a handful of scientists), with support from organizations advocating free market principles over government action. Also involved were financiers with strong ties to industries that would have much to lose were the United States to wean itself away from fossil fuels (Goldenberg 2012; Painter 2012). But neither this political challenge nor free market ideology completely explains the influence of the climate-skeptical agenda on public opinion. Many Americans who express skepticism about climate change science online and in social media also reject some free market ideas, such as the free flow of labor across borders (Wright et al. 2014).

I propose that a narrative-level examination of public commentary about climate change can provide additional insight into why climate skepticism resonates among so many in the public. Narrative helps explain the limited effectiveness of improved science communication. Something powerful in the story underlying climate skepticism-something beyond political motivations-captures the hearts 
and minds of many members of the public (see Lejano and Nero 2020).

To be clear, narrative is not everything. Among the public, one's opinion on climate change depends on factors such as personal political affiliation or the actions of lobbyists (McCright et al. 2014), but these factors all act in concert with a story that can capture people's imagination. Even if we do not yet know all about the factors and processes by which a narrative gains traction with the public over time, we can observe its presence today.

In this article, I will use the terms "climate skepticism" and "climate denial" as roughly interchangeable. However, note that some writers distinguish the terms, either placing skepticism on one end of the spectrum of disbelief and denial on the other, or treating skepticism as an encompassing condition and denial an extreme form of skepticism (Hobson and Niemeyer 2013).

THE POWER OF NARRATIVE. I propose that science communication may have had a limited effect because there is a science-skeptical narrative founded on issues that are prior to the climate issue. In other words, maybe public opinion was never about the science to begin with.

Ideological division undoubtedly lies at the heart of the climate science debate. Some scholars point to a link between climate skepticism in the United States and socio-political conservatism (e.g., McCright and Dunlap 2011), which has been referred to as a "culture war" (Hoffman 2012). ${ }^{1}$ This can be reinforced by the "echo chamber" of isolated discourse communities (Jamieson and Cappella 2008; Carmichael et al. 2017). Our ongoing work on ideological narratives lends credence to this. Previous research investigated how group discourse evolves into a specific type of narrative that can be identified as an ideology, which is a comprehensive worldview (Lejano and Dodge 2017). This research suggests how a strongly ideological narrative possesses properties, such as isolation from and closedness to other narratives, that are soon mirrored in the group itself.

Narrative and group share a two-way relationship: the narrative creates the group, and the group creates the narrative. A compelling narrative can attract more members to a movement and provide that movement with structure and rationale, while the emerging social network gives further definition to the group narrative-for this reason, these have been referred to as narrative networks (Lejano et al. 2013a; Ingram et al. 2019). The climate-skeptical narrative can help isolate the group's members from other narratives, at the same time as an already isolated group can, through an echo chamber effect, further work the narrative to become more and more extreme over time (Lejano and Dodge 2017).

An ideological narrative can go beyond a single-issue domain and saturate almost every other issue in social life. As our examples will show, the narrative thread easily weaves from climate skepticism to immigration to race and other issues. Frequently, climate deniers will invoke the idea of a global conspiracy-a hoax-behind climate science in the same way as they talk about conspiracies involving the liberal media, voter fraud, common core, Agenda 21, and others. It is a universal plot.

I propose that this universality is possible because all these issue-specific narratives share a common narrative thread-that is, they all can be built on the same basic story, or "metanarrative." It is easy to see how such a general storyline can be put to use to capture specific issues. ${ }^{2}$

The basic story, taken at its core, is possibly not even about climate science itself. It includes, but is not simply about, the tribalism of in-group versus out-group. While it remains to more carefully work out its narrative properties, we can sketch out a basic storyline by examining strident climate-science-skeptical talk online.

\footnotetext{
${ }^{1}$ It is important to keep in mind, however, that while one may point to an overlap between political conservatism and climate skepticism, one should not assume equivalence; indeed, one can subscribe to both climate science and a conservative outlook at the same time.

${ }^{2}$ Some explanation of terminology is warranted. A metanarrative is a general narrative scheme "which orders and explains knowledge and experience...[and] suppl[ies] the structure for individual narratives" (Stephens and McCallum 2013, p. 6). A general story providing a basic structure that reappears in more specific ways in individual stories is a special type of metanarrative called a "genetic narrative." We should also distinguish the terms "narrative" and "frame." A frame is a conceptual scheme that helps us interpret a situation in a certain way (Goffman 1974). A narrative is also a conceptual scheme but it takes a specific form, involving a sequence of connected events, characters, and setting. As such, a frame is a general device, and many subsume narrative under it (e.g., Hunt and Benford 1994). Others see a distinction (e.g., Polletta 1998), especially in the greater specificity, particularity, and theme development found in narrative. For example, while the general theme of "global conspiracy" can be a frame within which to view climate science, the narrative involves the complete story of who is involved in the conspiracy and why (e.g., "Climategate”).
} 
EXAMPLE. Some people do not hesitate to bring in a host of other issues into the public conversation about climate change. The patterns and themes are predictable. Take, for example, an article on city and state compliance with the Paris Agreement (prior to the Trump administration's withdrawal from the agreement $)^{3}$-here is a sample of comments found below it (punctuation and capitalization is as found in the original text):

- Must be the same "smart" Liberal Sanctuary Cities who harbor dangerous illegals.

- Our mayor...supporting the climate change thingy. Of course this idiot also has Houston as a sanctuary city. I did not vote for the creep. The Mexicans and blacks did.

- Mayors against guns, now we have mayors against jobs.

- Partisan activists that seem bent on trashing traditional American values so that we may one day accept the "official" change to radical Marxist globalism; the destruction of the Great Republic.

- Liberals are so stupid they think if a man puts on a dress it changes his chromosomes-and these morons are going to lecture others about science? LOL!

- Liberal socialist illegal alien lovers. It's happening.

Now, these snippets are too short to reveal entire narratives, but they reflect some common elements. First, there are comments on a new (socialist) world order. Comments on illegal immigration reflect, in part, a concern about redistribution. A racial element is also present (e.g., "Mexicans and blacks"). And there is constant reference to "them"- the liberals, the alt-left, socialists, immigrants, etc. So, there is often a confluence of non-climate-related social themes, even within discussions that are primarily about carbon and climate change.

Longer texts can be found in op-ed pieces. Many stay strictly within the bounds of a single topic, but one will find cases where the author's discussion touches on multiple, somehow related, topics. Take the following op-ed from a conservative writer's online blog (Caruba 2014):

\section{THE EPA IS AMERICA'S OTHER ENEMY}

While our attention is focused on events in the Middle East, a domestic enemy of the nation is doing everything in its power to kill the provision of electricity to the nation and, at the same time, to control every drop of water in the United States, an attack on its agricultural sector. That enemy is the Environmental Protection Agency.

Again, we see this easy convergence or overlap of differing issues, which suggests a narrative underlying the different issue narratives (on climate, agriculture, the Middle East, etc.).

While a proper narrative analysis requires systematic analysis of a greater corpus of texts, consider these comments from discussion threads concerning climate science, taken from a conservative online forum:

Those projections are based solely on computer climate models that can be, and are being, manipulated to get the desired results, i.e., warming in the next 100 years when everyone alive today will not be around to see if these computer projections are correct. The long-range goal of those politically motivated junk scientists in order to keep the government grants coming from leftist politicians whose goal is to control every aspect of our lives.

The goal of all liberal programs is to produce ever-increasing numbers of poor and ignorant people dependent on government handouts. ${ }^{4}$

This is not the point of Climate Change. The Left is claiming it is Manmade. This is the whole point of Climate Change. Man is causing this and the only way to prevent this is tax everyone. If you own a SUV, you will be taxed. If you own this or you own that, you will be taxed. Soon you will be taxed for exhaling every day. This is the reason for the Left supporting their Climate Change Hoax. ${ }^{5}$

And, to add another, here are some comments posted below an article on the Federal Climate Science Special Report ${ }^{6}$ :

\footnotetext{
${ }^{3}$ www.yahoo.com/gma/cities-states-aim-paris-accord-trumps-withdrawal-152I547|2--abc-news-topstories.html, accessed 3 May 2019.

${ }^{4}$ www.conservativesforum.com/cgi-bin/conservatives-forum/YaBB.pl?num=|4489|9630, accessed 21 January 2017.

${ }^{5}$ www.conservativesforum.com/cgi-bin/conservatives-forum/YaBB.pl?num=|48|223690/I0, accessed 24 January 2017.

${ }^{6}$ www.breitbart.com/politics/20 I7/II/08/delingpole-the-federal-climate-science-report-is-bunk-trump-must-fire-all-thecharlatans-responsible/, accessed 28 April 2019
} 
Every Leftist climate study proposes only one set of solutions: less individual liberty, higher taxes, "population control" of America and Europe, and more government control. What's new?

\author{
Marxism 101: Class warfare \\ Race warfare \\ Gender warfare \\ Ethnic warfare \\ Age warfare \\ Enviro-warfare \\ Religious warfare \\ (fill in the blank) warfare. Balkanize, divide, destroy. \\ Its the Marxist way.
}

[AGW is a SCAM!!!] It certainly is. From the same lovely people who brought us railway monopolies, fiat money, income tax, communism in Russia and China, fascism in Germany, poisoning of cancer patients and institutionalized child abuse.

These comments display common themes and evince "issue saturation," where the ideological storyline expands into a systemic, universal narrative (Lejano and Dodge 2017). This underlying metanarrative cuts across all issues of society, and multiple issues can be merged (e.g., climate and gun ownership). This is illustrated by blog comments such as the following (part of a thread labeled "'Global Warming' Biggest Science Scandal Ever”):

There are a few liberal ideas I cannot get out of my daughter's head, and this is one of them. Global warming, gay marriage, rape culture, etc. are a few in an otherwise very smart young lady's head that I am having trouble with!?

With saturation, we should find elements of a common metanarrative in texts about climate as well as non-climate issues. For example, here are some comments on immigration, taken from the same website:

Also at a grocery store I go to, a latina girl working the cash register born here and speaks perfect English but by illegal Mexican parents started speaking fluent Spanish to what I assume was a fence jumper. I commented on her Espanol and she informed me that she only speaks Spanish to her children because she wants that to be their first language. I had to bite my tongue to keep from causing a scene but I wanted to break something when I was walking out of the store. They are trying to change every aspect of American culture. No assimilation completely change this to a multi cultural multi lingual society. ${ }^{8}$

In working out the metanarrative, it helps to look at common plot elements that are found across these passages. There is, first of all, the fear of intrusion and loss of control in one's social domain, whether that is of government or outsiders to the community. Coupled with that is the element of change (social, economic, etc.). And, last, there is suspicion of the unknown, the foreign, and the new. At the same time, what used to be commonplace and familiar (e.g., white majority, carbon dioxide) is now being redefined as somehow problematic. These elements together create uncertainty about one's place in the world. To sum it up into a concise elemental plot:

While we once felt sure of our place in the world and our future, now, we are constantly being told that our ways (and, by extension, we) are somehow in the wrong. Others are imposing their ways and values on us and taking away what little control we had over our communities and our lives. They oppose us because they are completely alien to us.

No wonder, then, that slogans about "taking back" or "making the country great again" resonate with many people and many issues. In this light, climate skepticism is associated with a basic apprehension over loss of a familiar way of life and social order during an era when the American middle-class lifestyle is under threat. ${ }^{9}$ The familiar can be associated with cars, industry, consumption, development-all intimately linked with a carbon-centered economy. At the same time, there is also the element of intrusion, as elemental fears of big government, a social elite, or the general other intruding into one's personal domain. The genetic narrative is the "DNA" underlying subsequent, particular ideological claims made in diverse situations.

We should note, however, that reconstructing such a metanarrative always introduces a subjective

\footnotetext{
${ }^{7}$ www.conservativesforum.com/cgi-bin/conservatives-forum/YaBB.pl?num=|4234303|3, accessed 21 January 2017.

${ }^{8}$ www.conservativesforum.com/cgi-bin/conservatives-forum/YaBB.pl?num=|423248777, accessed 21 January 2017.

${ }^{9}$ While real incomes have increased appreciably (since the 1960s) for those in the upper 10th percentile bracket and also, to a lesser degree, for the 25th percentile category, they have stagnated for everybody else (as reported in www.pewresearch.org /fact-tank/2014/I0/09/for-most-workers-real-wages-have-barely-budged-for-decades/, accessed 17 November 2017).
} 
element, since the analyst has considerable discretion in deciding what elements the individual stories have in common. At the same time, the reconstructed narrative is not arbitrary. It is not surprising that it has much overlap with the "deep story" found recently by Hochschild in studying the deep resentment felt in a predominantly conservative community in Louisiana (Hochschild 2016).

DISCUSSION AND CONCLUSIONS. The examples cited above are not necessarily representative of most climate skeptics or even of climate skeptical comments found on conservative websites. Further study would be needed to gauge their pervasiveness within any given community or group. It is also easy to see, when considering a broader range of issues, that phenomena such as self-reinforcing narrativegroup dynamics, issue saturation, and tendencies toward conspiracy theory are not exclusive to the ideological right or left.

The examples do show, however, that the ideologically driven narratives skeptics adopt about climate change may be based on a story that is not primarily about the strength of climate science or even about climate, per se. The brief illustration above suggests a metanarrative based on an apprehension over social change and foreign intrusions into the conventional social order. It is the fear of a new, uncertain age where the familiar (white majority, carbon-based lifestyle) seems to be suspect and even vilified.

So then, how might one respond to the mistrust of climate science? The conversation would need to go beyond the science and onto what lies underneath, which is mistrust of change and fear of a changing social order. I do not suggest that efforts to better communicate climate science should be abandoned, but that they would be more effective when done in conjunction with other efforts to address non-scientific issues. The ideas presented herein should help identify ways to move forward.

Point I: Climate skeptics need to be listened to, taken seriously, and respected. Often, scientists talk in ways that alienate, rather than engage, the public (Lejano et al. 2013b). The problem is telling the public, in effect, "we talk, you listen," without taking the recipient of the message seriously enough to engage in actual dialogue.

The perception of being dismissed leads the public too easily to the idea that there is a conspiracy "out there" to suppress the truth. Dialogue requires mutual respect. Climate scientists have to make greater efforts not to seem dismissive or overbearing. This means acknowledging that it is completely reasonable to continue wondering if factors other than greenhouse gases might be driving climate change. This means responding, patiently, to claims made by climate skeptics-for example, explaining why the scholarly community would not be capable of conspiring around an artificial consensus in order to further careers and grant monies.

Point 2: Communities need to have ownership of change and society's responses to climate and other issues. Some people feel climate, immigration, and other issues are bringing their lifestyles into question. The resulting perception that they are being forced to change is part of what drives the rhetoric against government intrusion. Policy advocates need an earnest willingness toward dialogue, and they must resist the temptation to prescribe solutions without discussion. When scientists (too often) assume they have the solutions to climate change, they exacerbate the public's tendency to conflate the science with the policy, as often seen in online comments. Communicators should make clear that we have not figured out how, exactly, we should address climate change. The public needs to preserve its agency: People need to be listened to and allowed to take matters into their own hands.

Point 3: Climate communication has to speak to ideologically-driven fears. The example of immigration can give us much insight. While it is undoubtedly true that some anti-immigration sentiments are driven by racism, there is an ideological perspective on immigration that is about the loss of control of one's domain, self-respect, and security. So then, immigration rights advocates might begin championing the strengthening of local industry, tradition, and local communities at the same time as they fight for better rights for immigrants. In similar fashion, climate mitigation advocates need to be champions of the same issues, at the same time as they begin a dialogue around climate science. Advocates of climate action need to realize that their proposals are too easily mistaken as an injunction against people's aspirations for personal (and societal) progress. Carbon taxes are a prime example of this, and the discourse needs to go to small, positive steps (reducing energy use, walking more) that people can identify on their own and willingly take on. Small steps, in the right direction, may be the best option for engaging communities, notwithstanding the urgency of the problem.

There is also the need for so-called boundary agents who bridge the communication gap between scientists and communities. How does one begin a conversation 
with an ideologically hostile community? Perhaps it begins with finding members of the community who are willing to talk within their communities and negotiate relationships with scientists and other outsiders. Establishing relationships is the first step in overcoming an ideological divide (Lejano 2019).

These points may seem innocuous in the face of the strident, openly divisive discourse found in the United States (and elsewhere) today. However-and this is a leap of faith-sincere efforts to open up the dialogue may begin to improve the level of discussion. This is not an easy task. The scientific community can very understandably conclude that, as one scientist put it, "We cannot debate them, because they have no programs, no data, no formulas. There's nothing but ideology."10 And yet, even so, the need for sincere discussion becomes all the more important.

ACKNOWLEDGMENTS. The author thanks the editor, Jeff Rosenfeld, for insightful comments and suggested text, which have greatly improved the paper.

\section{REFERENCES}

Carmichael, J. T., R. J. Brulle, and J. K. Huxster, 2017: The great divide: understanding the role of media and other drivers of the partisan divide in public concern over climate change in the USA, 2001-2014. Climatic Change, 141, 599-612, https://doi.org/10. /s10584-017-1908-1.

Caruba, A., 2014: The EPA is America's other enemy. The Heartland Institute, accessed 2 November 2018, www.heartland.org/news-opinion/news/the-epa-is -americas-other-enemy?source=policybot.

Goffman, E., 1974: Frame Analysis: An Essay on the Organization of Experience. Harvard University Press, $586 \mathrm{pp}$.

Goldenberg, S., 2012: Leak exposes how Heartland Institute works to undermine climate science. Guardian, 15 February, www.theguardian.com /environment/2012/feb/15/leak-exposes-heartland -institute-climate.

Hobson, K., and S. Niemeyer, 2013: "What sceptics believe": The effects of information and deliberation on climate change scepticism. Public Understanding Sci., 22, 396-412, https://doi.org/10.1177 /0963662511430459.

Hochschild, A. R., 2016: Strangers in Their Own Land: Anger and Mourning on the American Right. The New Press, 370 pp.

Hoffman, A., 2012: Climate science as culture war. Stanford Social Innovation Review, Vol. 10, No. 4, 30-37, https://ssir.org/book_reviews/entry/climate_science _as_culture_war.

Hunt, S. A., and R. D. Benford, 1994: Identity talk in the peace and justice movement. J. Contemp. Ethnogr., 22, 488-517, https://doi.org/10.1177/089124194022004004.

Ingram, M., H. Ingram, and R. Lejano, 2019: Environmental action in the Anthropocene: The power of narrative networks. J. Environ. Policy Plann., 21, 492503, https://doi.org/10.1080/1523908X.2015.1113513.

Jamieson, K. H., and J. N. Cappella, 2008: Echo Chamber: Rush Limbaugh and the Conservative Media Establishment. Oxford University Press, 320 pp.

Leiserowitz, A., E. Maibach, C. Roser-Renouf, S. Rosenthal, and M. Cutler, 2017: Climate change in the American mind: May 2017. Yale University and George Mason University. Yale Program on Climate Change Communication, 46 pp., https://climate communication.yale.edu/publications/climate -change-american-mind-may-2017/.

Lejano, R. P., 2019: Climate change and the relational city. Cities, 85, 25-29, https://doi.org/10.1016/j.cities .2018.12.001.

— ideology: The adversarial turn and climate skepticism in the USA. Policy Sci., 50, 195-215, https://doi .org/10.1007/s11077-016-9274-9.

- , and S. Nero, 2020: The Power of Narrative: Climate Skepticism and the Deconstruction of Science. Oxford, in press.

—, M. Ingram, and H. Ingram, 2013a: The Power of Narrative in Environmental Networks. MIT Press, 248 pp.

—, J. Tavares-Reager, and F. Berkes, 2013b: Climate and narrative: Environmental knowledge in everyday life. Environ. Sci. Policy, 31, 61-70, https://doi .org/10.1016/j.envsci.2013.02.009.

McCright, A. M., and R. E. Dunlap, 2011: The politicization of climate change and polarization in the American public's views of global warming, 2001-2010. Sociol. Quart., 52, 155-194, https://doi .org/10.1111/j.1533-8525.2011.01198.x.

,-- , and C. Xiao, 2014: Increasing influence of party identification on perceived scientific agreement and support for government action on climate change in the United States, 2006-12. Wea. Climate Soc., 6, 194-201, https://doi.org/10.1175 /WCAS-D-13-00058.1.

National Science Board, 2018: Science and engineering indicators 2018. National Science Foundation, accessed 22 April 2018, www.nsf.gov/statistics/2018 /nsb20181/report/.

\footnotetext{
${ }^{10}$ Dr. Michio Kaku at http://cnnpressroom.blogs.cnn.com/2014/02/23/climate-change-is-not-debateable/, accessed 23 January 2017.
} 
Oreskes, N., and E. Conway, 2010: Merchants of Doubt. Bloomsbury, $368 \mathrm{pp}$.

Painter, J., 2012: Communicating uncertainties: Climate skeptics in the international media. Communication, Controversies and Uncertainty Facing the Scientific Consensus on Climate Change, J.-L. Piñuel-Raigada et al., Eds., Sociedad Latina de Comunicación Social, 187.

Pew Research Center, 2009: Public praises science; Scientists fault public, media. Accessed 17 August 2009, http://people-press.org/report/528/.
Polletta, F., 1998: Contending stories: Narrative in social movements. Qual. Sociol., 21, 419-446, https://doi .org/10.1023/A:1023332410633.

Stephens, J., and R. McCallum, 2013: Retelling Stories, Framing Culture: Traditional Story and Metanarratives in Children's Literature. Routledge, $316 \mathrm{pp}$.

Wright, M., M. E. Levy, and J. Citrin, 2014: Conflict and consensus on American public opinion on illegal immigration. School of Public Affairs Research Paper 2014-0006, American University, 54 pp., https://doi .org/10.2139/ssrn.2476001. 